Dikirim: 11 Juni 2016 Diterbitkan: 1 Juli 2016

\title{
Eksplorasi ancaman peringatan kesehatan bergambar pada kemasan rokok
}

\section{Exploration of pictorial health warnings threat on cigarette packs}

Fahmi Baiquni ${ }^{1}$, Fatwa Sari Tetra Dewi1, Rendra Widyatama ${ }^{2}$

\begin{abstract}
Purpose: This study was conducted to explore the threat of pictorial health warnings on cigarette packages. Methods: This research was a qualitative study with grounded theory approach, conducted in the districts of Depok Sleman, Yogyakarta. The informants were residents in the Depok sub district. The number of informants were 14 people. Informants were selected using a maximum variation technique. The variations of informants were based on their knowledge, attitudes and smoking behavior. Data were collected by in-depth interviews and observations. Results: The perception of threats after seeing a picture warnings on cigarette packs were feelings of danger and fear, disgust, pity, worry, and mediocrity. The efficacy after seeing a picture warnings on cigarette packs was image believing and individual impact after viewing images. Conclusion: The threat of pictorial warnings are not only affected by the warning image itself but also the experience of the viewer and aspects of the warning image such as color, clarity of image, and message content.
\end{abstract}

Keywords: pictorial warning; extended parallel process model; smoking warning

\footnotetext{
${ }^{1}$ Departemen Biostatistik, Epidemiologi, dan Kedokteran sosial, Fakultas Kedokteran, Universitas Gadjah Mada (Email: fahmibaiquni@mail.ugm.ac.id)

${ }^{2}$ Program Studi Ilmu Komunikasi, Fakultas Sastra, Budaya dan Komunikasi, Universitas Ahmad Dahlan
} 


\section{PENDAHULUAN}

Asap rokok mengandung lebih dari 7000 jenis zat kimia yang berbahaya bagi kesehatan (1). Orang yang mengkonsumsi rokok berhadapan dengan peningkatan resiko terkena berbagai macam jenis kanker, penyakit jantung, strok, kerusakan pada paru-paru yang akan menyebabkan penyakit asma emfisema, dan bronkitis kronis (1). Setiap tahun hampir 6 juta orang meninggal karena rokok (2).

Pemerintah Republik Indonesia telah menerbitkan Peraturan Pemerintah No 109 tahun 2012 tentang pengamanan bahan yang mengandung zat adiktif berupa produk tembakau bagi kesehatan. Peraturan pemerintah ini diterbitkan pada 24 Desember 2012. Para produsen rokok harus sudah menerapkan peraturan ini paling lambat 18 bulan sejak peraturan tersebut diterbitkan yaitu 24 Juni 2014. Peraturan tersebut sejalan dengan beberapa penelitian yang menunjukkan bahwa gambar peringatan pada bungkus rokok efektif untuk menurunkan perilaku merokok. Penelitian yang dilakukan oleh Blanton menunjukkan bahwa gambar peringatan (pictorial warning) dapat menurunkan ketertarikan perokok aktif terhadap rokok (4). Penelitian yang dilakukan oleh Thraser bahwa label peringatan kesehatan berbentuk gambar lebih efektif daripada label peringatan kesehatan bentuk teks (5).

Gambar peringatan dapat meningkatkan imajinasi perokok terhadap konsekuensi buruk dari perilaku merokok (6). Penelitian Hammond menunjukkan bahwa peringatan dalam bentuk grafis/gambar penyakit merupakan yang paling efektif bagi remaja dan orang dewasa (7). Peringatan memperlihatkan ancaman penyakit akibat merokok lebih efektif daripada peringatan memperlihatkan sisi kesehatan akibat tidak merokok $(8,9)$. Hingga kini belum terdapat evaluasi dari pemerintah terkait hal tersebut. Oleh karena itu penting untuk dikaji bahwa gambar peringatan pada bungkus rokok yang telah beredar di Indonesia saat ini apakah benar-benar sesuai untuk memberikan peringatan kepada para perokok. Perlu untuk dilakukan kajian mengenai gambar-gambar mana yang memiliki dampak terbesar terhadap masyarakat, dan bagaimana gambar-gambar tersebut harus diubah agar dapat terus mempertahankan fungsinya sebagai gambar peringatan (5).

Penelitian ini menggunakan kerangka Extended parallel process model (EPPM) atau yang sering disebut sebagai teori fear appeal untuk melakukan kajian gambar (10). Extended parallel menjelaskan jika suatu pesan kesehatan dapat memunculkan ancaman dengan tingkatan yang cukup maka akan menimbulkan perasaan takut (11). Perasaan takut tersebut akan mendorong munculnya keyakinan ancaman yang kemudian akan mengarahkan pada perilaku sebagai respon dari peringatan tersebut. Jika ancaman tidak muncul maka tidak akan ada respon apapun yang muncul setelah melihat atau membaca suatu pesan atau gambar peringatan. Penelitian ini bertujuan untuk mengkesplorasi ancaman yang dimunculkan oleh peringatan bergambar pada kemasan rokok.
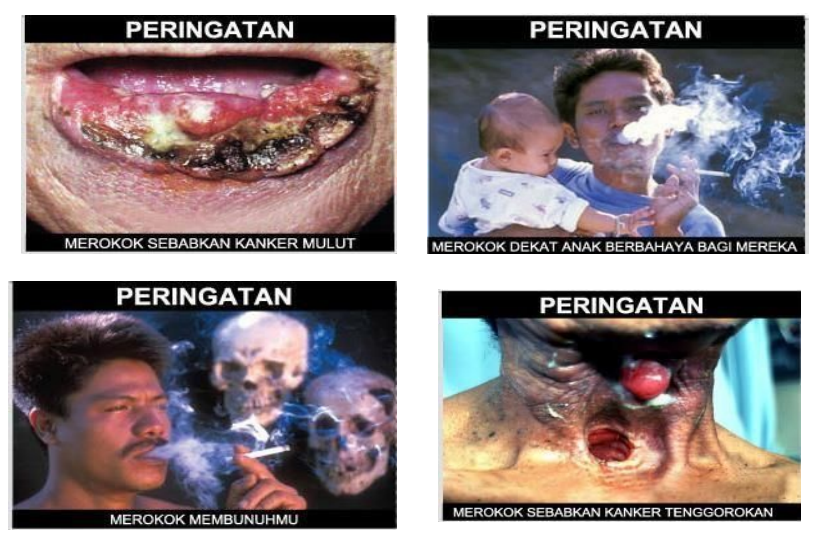

Gambar 1. Peringatan bergambar pada kemasan rokok (Permenkes No 28 th. 2013)

\section{METODE}

Penelitian ini merupakan penelitian kualitatif dengan pendekatan grounded theory. Penelitian dilaksanakan di Kecamatan Depok Kabupaten Sleman Yogyakarta dengan subjek penelitian adalah penduduk kecamatan depok yang tinggal di Desa Caturtunggal dan Desa Maguwoharjo. Pemilihan informan dilakukan menggunakan maximum variation. Variasi informan dalam penelitian ini adalah perilaku (merokok/tidak merokok), pengetahuan tentang bahaya rokok, dan sikap terhadap bahaya rokok, (setuju/tidak setuju bahwa rokok berbahaya). Jumlah sampel dalam penelitian ini adalah 20 informan.

Informan penelitian ini terdiri dari laki-laki dan perempuan. Usia informan termuda adalah 18 tahun dan yang paling tua berusia 61 tahun. Latar belakang pendidikan informan bervariasi dari tidak menempuh pendidikan formal hingga S2. Mayoritas informan berprofesi sebagai buruh dan karyawan swasta. Jumlah keseluruhan informan adalah 20 orang yang terdiri atas 13 orang laki-laki dan 7 orang perempuan.

Pengambilan data dilakukan dengan melakukan wawancara mendalam. Instrumen yang digunakan adalah pedoman wawancara mendalam terhadap 
perokok dan non perokok yang berisi beberapa pertanyaan untuk menggali perilaku, pengetahuan dan sikap informan serta ancaman dan keyakinan ancaman informan setelah melihat gambar peringatan. buku catatan dan alat bantu rekam digunakan untuk membantu pengumpulan data. Semua data yang telah diperoleh kemudian ditranskrip dan dilakukan pengkodean dengan menggunakan software opencode 4.02. Hasil transkrip tersebut kemudian dikoding dengan menuliskan maknanya. Kemudian, disusun kategori dengan cara mengelompokkan koding-koding yang memiliki makna serupa. Kemudian masingmasing kategori dihubungkan hingga mendapatkan pola tertentu berupa axial coding. Setelah semua tahap dilakukan, hasil dari data yang didapatkan, disajikan dalam bentuk narasi, tabel maupun gambar.

\section{HASIL}

Secara keseluruhan ancaman setelah melihat gambar peringatan pada kemasan rokok dipengaruhi oleh aspek gambar yang mencakup kejelasan konten, tampilan bahaya, dan tampilan keparahan akibat rokok. Hal lain yang memengaruhi munculnya ancaman dan keyakinan ancaman adalah pengalaman informan, status merokok, harga rokok dan keyakinan tentang sumber penyakit.

Hasil wawancara menunjukkan bahwa ancaman peringatan bergambar muncul dalam bentuk perasaan takut, jijik, kasihan, khawatir dan biasa saja. Munculnya perasaan tersebut dipengaruhi oleh persepsi yang dimiliki oleh informan. Perasaan takut, jijik, kasihan, dan khawatir muncul pada informan yang mempersepsikan bahaya sebagai suatu bahaya, sedangkan informan yang tidak mempersepsikan peringatan bergambar sebagai suatu peringatan bahaya akan merasa biasa saja. Selain itu, munculnya perasaan dipengaruhi oleh aspek peringatan bergambar. Peringatan yang menampilkan gambar yang berbahaya dan keparahan akibat rokok akan dapat memunculkan persaan takut, jijik, kasihan dan khawatir, sedangkan peringatan yang tidak menunjukkan bahaya dan keparahan bahaya akibat rokok tidak dapat memunuclkan persaan takit, jijik, kasihan ataupun khawatir.

Munculnya perasaan takut, jijik, kasihan dan khawatir juga dipengaruhi oleh pengalaman dan status merokok informan. Pengalaman yang mendukung bahwa rokok berbahaya akan mendorong munculnya rasa takut, jijik, kasihan, ataupun khawatir, sedangkan pengalaman yang tidak mendukung bahwa rokok berbahaya akan memunuclkan persaan biasa saja pada diri informan ketika melihat peringatan bergambar.
Selain itu, status sebagai non perokok membuat informan merasa tidak akan terkena bahaya rokok.

"yang pertama karena..ini terbuka ya.. sama dengan yang kanker mulut tadi ada nanah, ini bahkan sampai isinya pasti darah ini (menunjuk bulatan merah pada gambar kanker tenggorokan) sudah sampai seperti itu, kemudian kulitnya.. sudah jadi kering sekali..efeknya ternyata tubuh kita digerogoti sekali ya...ya.. memang tidak ada bagus bagusnya merokok“ (MT, non perokok, perempuan, 26 th, S2, tidak mengetahui bahaya rokok, setuju rokok berbahaya)

"kalau saya ya biasa saja mas karena saya tidak merokok, yang jelas itu...” (BO, non perokok, 38 th, laki-laki, SD, mengetahui bahaya rokok, setuju rokok berbahaya)

"kalau anak kecil.. lihat ini (menunjuk gambar orang merokok dengan anak di dekatnya) ya paling berpikir, wah.. itu seperti adik saya ya itu digendong.. cuma begitu saja taunya.. itu dari penglihatan anak sampai dewasa yang lihat, tidak mengerikan, yang ini terlihat seperti orang tua momong anak kalau ini...” (SJ, non perokok, laki-laki, 38 th, STM, mengetahui bahaya rokok, setuju rokok berbahaya)

"ya jijik, ngeri ah, sampai nanahan juga yang ini menakutkan (sambil menjauhkan gambar)" (WD, perokok, Laki-Laki, 30 th, SMP, tidak mengetahui bahaya rokok, setuju rokok berbahaya)

"ya kasihan juga ya.. kakak saya begini saya lihat ya kasihan.ya lihat badannya sampai kecil begitu .. ya berapa ya baru 2 bulan

"ya.. aktivitas itu, kan dulu mengelas itu sekarang ya itu sudah tidak bisa aktivitas apa-apa hanya tiduran, saya membayangkan kasihan ya, prihatin juga..” (MT, non perokok, perempuan, 26 th, S2, tidak mengetahui bahaya rokok, setuju rokok berbahaya)

Peringatan dengan ancaman tertinggi. Hasil wawancara menunjukkan bahwa secara umum gambar - gambar yang dianggap paling menakutkan atau mengerikan menurut informan adalah gambar kanker mulut dan gambar kanker paru-paru. Gambar kanker mulut dianggap sebagai gambar yang paling mengerikan karena pengalaman informan sebagai perokok. Informan menganggap bahwa mulut merupakan bagian tubuh yang digunakan untuk merokok sehingga gambar tersebut merupakan gambar yang paling mungkin terjadi. Selain itu, juga 
kanker mulut merupakan akibat rokok yang langsung terlihat.

"yang satu (gambar kanker mulut) kan merokok kan lewat mulut, nah secara langsung yang terkena rokok kan bibir sih ya.. jadi ya agak masuk sih ini, mungkin karena apa iritasi atau karena lagi luka bibirnya jadi seperti itu, atau bibirnya sensitif terkena rokok jadi seperti itu, bisa saja...” (AR, non peroko, laki-laki, 18 th, mengetahui bahaya rokok, tidak setuju rokok berbahaya)

“ (terdiam sekitar 10 detik sambil terus memandang gambar kanker mulut) mungkin alasan ini sekali sih Tapi karena kalau ini yang paling efeknya bisa langsung terlihat jelas begitu efeknya ada.. dalam artian kalau ini” (MT, non perokok, perempuan, 26 th, S2, tidak mengetahui bahaya rokok, setuju rokok berbahaya)

Gambar kanker paru - paru dianggap sebagai gambar yang paling menakutkan karena gambar tersebut menunjukkan gambar yang jelas. Informan menggap gambar tersebut sebagai gambar yang paling mengerikan karena memperlihatkan sayatan dan paru-paru yang menghitam

"ya.. jelas dari sekian hampir separuh tubuh kelihatan semua... terus sayatannya itu, sayatan sayatan ini kemudian dadanya hitam, hitamnya ini dampak dampaknya ini" (SJ, non perokok, laki-laki, 38 th, STM, mengetahui bahaya rokok, setuju rokok berbahaya)

Gambar kanker paru-paru dianggap sebagai gambar yang paling menakutkan karena menunjukkan keparahan akibat rokok. Menurut informan, gambar tersebut paling menakutkan karena jika terkena kanker paru-paru dapat meninggal dunia.

"pakai ini ya.. ini kan terkena ini (sambil menunjuk gambar kanker paru paru) bisa langsung.. mati” (WD, perokok, Laki-Laki, 30 th, SMP, tidak mengetahui bahaya rokok, setuju rokok berbahaya)

Gambar peringatan yang dianggap paling memunculkan rasa jijik menurut informan adalah gambar kanker mulut. Hal tersebut karena menurut informan gambar tersebut memperlihatkan nanah.

“yang mulut” (WD, perokok, Laki-Laki, 30 th, SMP, tidak mengetahui bahaya rokok, setuju rokok berbahaya) “ada nanah nanahya” (WD, perokok, Laki-Laki, 30 th, SMP, tidak mengetahui bahaya rokok, setuju rokok berbahaya)

Hasil wawancara menunjukkan gambar peringatan kanker mulut dan gambar peringatan kanker paruparu merupakan gambar yang paling memunculkan perasaan tidak nyaman. Gambar - gambar tersebut memunculkan perasaan tidak nyaman pada mayoritas informan karena menunjukkan kerentanan dan keparahan dari akibat rokok. Gambar itu dipersepsikan sebagai gambar ancaman bahaya tertinggi yang paling menunjukkan dampak rokok paling parah.

Peringatan dengan ancaman terendah. Gambar yang dianggap oleh informan paling biasa saja (paling tidak menakutkan) adalah gambar orang merokok dengan anak didekatnya dan gambar orang merokok dengan asap membentuk tengkorak. Gambar orang merokok dianggap sebagai gambar yang paling biasa saja karena gambar tersebut tidak menjijikan. Selain itu, menurut informan rokok tidak terlalu berbahaya bagi perokok pasif karena tidak selalu terpapar asap rokok.

"ya itu yang menggendong anak itu lumayan itu.. tidak memperlihatkan.. apa ya, menjijikan, tidak terlalu jijik kalau itu, karena ini anak kecil ya juga menasihati” (YN, non perokok, 35 th, perempuan, tidak menempuh pendidikan formal, tidak mengetahui bahaya rokok, setuju rokok berbahaya)

"mungkin karena kalau perokok pasif itu kan tidak.. tidak selalu ya, tidak seperti yang perokok aktif kan dia sekali.. apa setiap saat menghgisap sendiri, kalau perokok pasif itu kan mungkin hanya kadang kadang” (ST, perokok, laki-laki, 46 th, SMA, mengetahui bahaya rokok, setuju rokok berbahaya)

Gambar orang merokok dengan asap membentuk tengkorak dianggap sebagai gambar yang paling biasa karena gambar tersebut hanya menunjukkan orang yang merokok seorang diri.

"ya ini (menunjukkan gambar merokok dan tengkorak), merokok sendirian" (AR, non perokok, laki-laki, 18 th, mengetahui bahaya rokok, tidak setuju rokok berbahaya)

Hasil wawancara di atas menunjukkan bahwa gambar peringatan orang merokok dengan anak disampingnya dan gambar peringatan orang merokok 
dengan asap membentuk tengkorak merupakan gambar-gambar peringatan yang paling biasa saja dan tidak memunculkan perasaan tidak nyaman. gambar -gambar tersebut paling biasa saja karena gambargambar tersebut adalah gambar yang menurut informan tidak menunjukkan kerentanan dan keparahan dari akibat rokok. Gambar-gambar tersebut juga hanya dianggap sebagai peringatan ringan. Hasil tersebut menunjukkan bahwa gambar peringatan yang memiliki ancaman terendah adalah gambar peringatan yang paling tidak menunjukkan kerentanan dan kaparahan akibat rokok.

\section{BAHASAN}

Hasil penelitian menunjukkan bahwa peringatan bergambar pada kemasan rokok memunculkan perasaan terancam maupun tidak terancam baik pada informan perokok maupun non perokok. Ancaman muncul dalam bentuk rasa takut, jijik, kasihan, khawatir, dan prihatin. Informan yang tidak merasakan takut, jijik, kasihan, khawatir, atau prihatin ketika melihat gambar peringatan maka dalam dirinya tidak muncul ancaman. Hal tersebut sesuai dengan yang disampaikan oleh Gore dan Bracken bahwa suatu pesan peringatan yang mengancam akan memunculkan perasaan takut pada diri orang yang melihat atau membacanya. Sedangkan pesan peringatan yang tidak memiliki ancaman tidak akan memunculkan apapun pada diri orang yang melihat atau membacanya (10).

Dengan demikian, ancaman yang muncul setelah melihat gambar peringatan dapat diketahui dari ekspresi perasaan setelah melihat peringatan tersebut. Jika peringatan bergambar dapat mengekspresikan perasaan takut atau perasaan tidak nyaman maka peringatan tersebut dapat memunculkan ancaman. Jika peringatan bergambar tidak dapat mengekspresikan perasaan takut atau perasaan tidak nyaman maka peringatan tersebut tidak dapat memunculkan ancaman. Berdasarkan hasil penelitian, peringatan yang dapat memunculkan ancaman adalah peringatan bergambar kanker mulut, kanker tenggorokan dan paru-paru menghitam karena kanker. Gambar peringatan orang merokok dengan asap membentuk tengkorak dan orang merokok dengan anak di dekatnya tidak cukup kuat untuk memunculkan ancaman karena sebagian besar informan tidak merasa takut ketika melihat kedua gambar tersebut. Hal ini terjadi karena kedua peringatan bergambar tersebut tidak menampilkan bagian tubuh yang terkena penyakit. Hasil tersebut sesuai dengan apa yang disampaikan oleh Cameron dan Williams (12) yaitu peringatan yang menampilkan gambar-gambar anggota tubuh yang terkena penyakit akan lebih efektif untuk memunculkan ancaman.

Hasil penelitian menunjukkan bahwa munculnya ancaman setelah melihat peringatan bergambar dipengaruhi oleh persepsi terhadap peringatan bergambar, pengalaman yang dialami diri sendiri atau orang lain, dan aspek peringatan bergambar (kejelasan gambar dan kejelasan tulisan). Perasaan takut, jijik, kasihan, dan khawatir muncul pada orang yang mempersepsikan peringatan bergambar sebagai bahaya. Sementara itu, orang yang tidak mempersep- sikan peringatan bergambar sebagai bahaya akan merasa biasa saja ketika melihatnya. Hal tersebut sesuai dengan apa yang disampaikan oleh Sjoberg bahwa persepsi bahaya akan mendorong munculnya rasa takut pada individu (13).

Persepsi terhadap peringatan bergambar dipengaruhi oleh kejelasan gambar dan tulisan. Hasil penelitian menunjukkan bahwa persepsi bahaya lebih banyak muncul pada peringatan bergambar kanker mulut, kanker tenggorokan dan paru-paru yang menghitam karena kanker. Hal ini dikarenakan peringatan-peringatan tersebut lebih menunjukan keparahan akibat rokok secara nyata. Sesuai dengan pernyataan Slovic yang menyatakan bahwa persepsi bahaya terhadap suatu peringatan akan semakin muncul jika peringatan tersebut menampilkan keparahan akibat dari suatu perilaku (14).

Pengalaman yang mendukung bahwa rokok berbahaya dan gambar serta tulisan yang jelas akan mendorong munculnya persepsi bahwa peringatan bergambar tersebut merupakan bahaya. Witt dan Riley menyampaikan bahwa persepsi merupakan penginderaan informasi yang berasal dari stimulus-stimulus yang diterima (15). Berdasarkan opini tersebut dapat diketahui bahwa persepsi terbentuk dari penginderaan terhadap beberapa stimulus. Pengalaman, gambar dan tulisan merupakan stimulus yang akan memengaruhi munculnya persepsi setelah melihat peringatan bergambar. Jika pengalaman, gambar dan tulisan memberikan stimulus bahaya maka individu yang melihat peringatan bergambar akan mempersepsikan bahwa peringatan tersebut menunjukkan bahaya.

Hasil penelitian juga menunjukkan bahwa munculnya ancaman dipengaruhi oleh aspek peringatan bergambar (kejelasan gambar dan kejelasan tulisan). Laughery and Wogalter menyampaikan bahwa desain suatu peringatan seperti tulisan, ukuran, warna dan gambar akan memengaruhi bagaimana individu menanggapi peringatan tersebut (16). Hasil dalam 
penelitian ini menunjukkan bahwa peringatan dengan gambar yang menunjukkan keparahan dan tulisan yang jelas dapat lebih memunculkan ancaman. Kejelasan merupakan salah satu hal penting dalam suatu pesan peringatan untuk memunculkan ancaman pada individu yang melihatnya (16).

Hasil penelitian menunjukkan bahwa peringatan bergambar dengan ancaman tertinggi adalah kanker mulut dan kanker paru-paru. Peringatan kanker mulut memunculkan ancaman tertinggi, karena dianggap sebagai peringatan bergambar yang paling menakutkan dan menjijikan. Peringatan bergambar tersebut paling menakutkan karena jika terkena penyakit yang ditunjukkan oleh peringatan tersebut (kanker mulut) akan dapat langsung terlihat oleh orang lain. Sementara itu, peringatan tersebut dianggap sebagai peringatan yang paling menjijikan karena memperlihatkan keparahan. Peringatan kanker paru-paru memunculkan ancaman tertinggi karena dianggap juga sebagai gambar yang paling menakutkan. Peringatan tersebut dianggap paling menakutkan karena memperlihatkan keparahan akibat rokok. Hasil tersebut menunjukkan bahwa peringatan bergambar yang memiliki ancaman paling tinggi adalah peringatan yang menunjukkan keparahan akibat rokok. Wolgater menyampaikan bahwa gambar peringatan yang lebih menunjukkan keparahan akan lebih dapat memengaruhi individu yang melihatnya (16). Selain itu, peringatan tersebut memiliki ancaman tertinggi karena memperlihatkan akibat rokok pada organ luar tubuh yang dapat langsung terlihat. Peringatan bergambar yang memperlihatkan akibat buruk pada organ luar tubuh dapat lebih efektif dalam memunculkan ancaman (7). Keterbatasan dalam penelitian ini adalah pengambilan data hanya dilakukan dalam satu waktu. Sebaiknya dilakukan juga pengambilan data dalam jangka waktu yang berkala supaya mendapatkan gambaran hasil yang lebih luas.

\section{SIMPULAN}

Peringatan yang dapat memunculkan ancaman adalah peringatan yang menunjukkan bahaya dan keparahan akibat rokok. selain itu, peringatan bergambar harus mudah dipahami. Selain itu, tampilan organ tubuh terkena penyakit yang nyata dapat lebih mendorong munculnya ancaman pada diri individu yang melihatnya.

Saran dalam penelitian ini adalah peringatan bergambar sebaiknya menggunakan gambar-gambar yang menampilkan bahaya dan keparahan akibat rokok.Peringatan bergambar pada kemasan rokok sebaiknya lebih diperbesar ukurannya dan diperluas cakupan gambarnya supaya lebih mudah untuk dipahami

\section{Abstrak}

Tujuan: Penelitian ini bertujuan untuk mengeksplorasi ancaman yang ditimbulkan oleh gambar peringatan yang terdapat pada bungkus rokok. Metode: Penelitian ini menggunakan metode kualitatif dengan desain grounded theory untuk mengeksplorasi bagaimana dari ancaman yang muncul setelah melihat gambar peringatan yang ada pada kemasan rokok. Pengumpulan data dilakukan dengan wawancara mendalam dan observasi. Hasil: Ancaman yang muncul setelah melihat gambar peringatan pada kemasan rokok muncul karena adanya perasaan takut, jijik, kasihan, khawatir, biasa saja. Selain itu, terdapat pengalaman dan aspek gambar yang memengaruhi munculny ancaman dan keyakinan ancaman. Simpulan: Munculnya ancaman tidak hanya dipengaruhi oleh gambar peringatan tetapi juga pengalaman dan aspek gambar peringatan. Gambar peringatan yang lebih menakutkan dan memunculkan keparahan lebih cenderung memberikan efek ancaman.

Kata kunci: gambar peringatan; bungkus rokok; extended parrallel process model

\section{PUSTAKA}

1. Centers for Disease Control and Prevention. What You Need To Know About Smoking: Advice From Surgeon General' s Reports on Smoking and Health [Internet]. Surgeon General's Report on Smoking \& Health. Atlanta; 2014. Available from: www.cdc.gov

2. WHO. Tobacco [Internet]. Media Center. 2014 [cited 2015 Mar 7]. Available from: www.who.int

3. Presiden Republik Indonesia. Peraturan Pemerintah No 109 Tahun 2012 tentang Pengamanan Bahan Yang Mengandung Zat Adiktif Berupa Produk Tembakau Bagi Kesehatan. 109 Tahun 2012 Indonesia; 2012.

4. Blanton H, Snyder LB, Strauts E, Larson JG. Effect of Graphic Cigarette Warnings on Smoking Intentions in Young Adults. PLoS One.

5. 2014;9(5):1-8.

6. Thraser JF, Arillo-Santillan E, Villalobos V, Perez-Hernandez R, Hammond D, Carter J, et al. Can pictorial warning labels on cigarette packages address smoking-related health disparities ? Field experiments in Mexico to assess pictorial warning label content. Cancer Causes Control. 2012;23:69-80.

7. Pepper JK, Cameron LD, Reiter PL, Mcree A, Brewer NT. Non-Smoking Male Adolescents, Reactions to Cigarette Warnings. PLoS One. 2013;8(8). 
8. Hammond D, Thrasher J, Reid JL, Driezen P, Boudreau C, Santilla EA. Perceived effectiveness of pictorial health warnings among Mexican youth and adults: a population-level intervention with potential to reduce tobacco- related inequities. Cancer Causes Control. 2012;23:57-67.

9. Verde C. For the record. Can Med Assoc J. 2012;184(7):357-9.

10. Durkin S, Bayly M, Cotter T, Mullin S, Wakefield M. Potential effectiveness of anti-smoking advertisement types in ten low and middle income countries: do demographics, smoking characteristics and cultural differences matter? Soc Sci Med [Internet]. 2013 Dec [cited 2014 Oct 3];98:204-13. Available from: www.ncbi.nlm.nih.gov

11. Gore TD, Bracken CC. Testing the Theoretical Design of a Health Risk Message : Reexamining the Major Tenets of the Extended Parallel Process Model. 2005;32(February):27-41.

12. Russell JC, Smith S, Novales W, Massi Lindsey LL, Hanson J. Use of the extended parallel processing model to evaluate culturally relevant kernicterus messages. J Pediatr Health Care [Internet]. Elsevier Ltd; 2013 Jan [cited 2014 Oct 29];27(1):33-40. Available from: www.ncbi.nlm.nih.gov

13. Cameron LD, Williams B. Which Images and
Features in Graphic Cigarette Warnings Predict Their Perceived Effectiveness? Findings from an Online Survey of Residents in the UK. Ann Behav Med. 2015;49:639-49.

14. Sjoberg L. Specifying factors in radiation risk perception. Skand J Psychol. 2000;41:169-74.

15. Bond L, Nolan T. Making sense of perceptions of risk of diseases and vaccinations: a qualitative study combining models of health beliefs, decision-making and risk perception. BMC Public Health. 2011;11(943):1- 14.

16. Witt JK, Riley MA. Discovering your inner Gibson : Reconciling action- specific and ecological approaches to perception - action. Psychon Bull Rev. 2014;21:1353-70.

17. Laughery KR, Wogalter MS. A three-stage model summarizes product warning and environmental sign research. Saf Sci [Internet]. Elsevier Ltd; 2014 Jan [cited 2014 Oct 27];61:3-10. Available from: http://linkinghub.elsevier.com

18. Menteri Kesehatan Republik Indonesia. Peraturan Menteri Kesehatan Republik Indonesia Nomor 28 Tahun 2013 Tentang Pencantuman Peringatan Kesehatan dan Informasi Kesehatan Pada Kemasan Produk Tembakau. 28 Tahun 2013 Indonesia; 2013 
Berita Kedokteran Masyarakat, Volume 32 No. 7 Tahun 2016 